\title{
147. 波長の異なる蛍光ランプによる長日植物の生育制御方法
}

\section{ーシュッコンカスミソウに対する光質の違いの影薝一 \\ 森山 厳興勝田 敬子 金浜 耕基}

（東芝ライテック株式会社）（東北大学大学院農学研究科）

\section{1. 目的}

照明が必要な花卉の栽培例としては、短日植物のキクでの電照栽培が有名である。近年のガーデニ ングブームにより、色鮮やかな長日植物の需要が高まってきているが、長日植物の光に対する反応入 カニズムについては明らかにされていない。そこで、長日植物が、波長の異なる蛍光ランプに対して どのような反応をするか実験により調べ、生育制御に必要な光質について検討を行った。

\section{2. 材料および方法}

長日植物（シュッコンカスミソウ ‘ブルストルフェアリー’）を供試した。植物の光受容体として知 られているフィトクロムおよびクリプトクロムの光吸収領域に発光ピークを有する青色電球形蛍光ラ ンプ $(14 \mathrm{~W})$ 、赤色電球形蛍光ランプ $(14 \mathrm{~W}$ 試 作品)、遠赤色電球形蛍光ランプ(14W 試作品) を、縦 $100 \mathrm{~cm} \times$ 横 $70 \mathrm{~cm} \times$ 高さ $115 \mathrm{~cm}$ の遮光 フィルムで覆った試験区に 1 灯設置した。 9:00〜 17:00 を自然光、17:00〜9:00 蛍光ラ ンプで照明した。各試験区に設置したランプ の分光分布を図 1 に、栽培面における水平面 照度および光量子束密度を表 1 に示す。各処 理区の栽培温度は、昼間 $(6: 00 \sim 18: 00)$ は $24^{\circ} \mathrm{C}$ 、 夜間(18:00-6:00)は $19^{\circ} \mathrm{C}$ で管理し、20 週間栽 培した。開花到達日数、開花率、草丈、葉数 および節間長について生育調查を実施した。

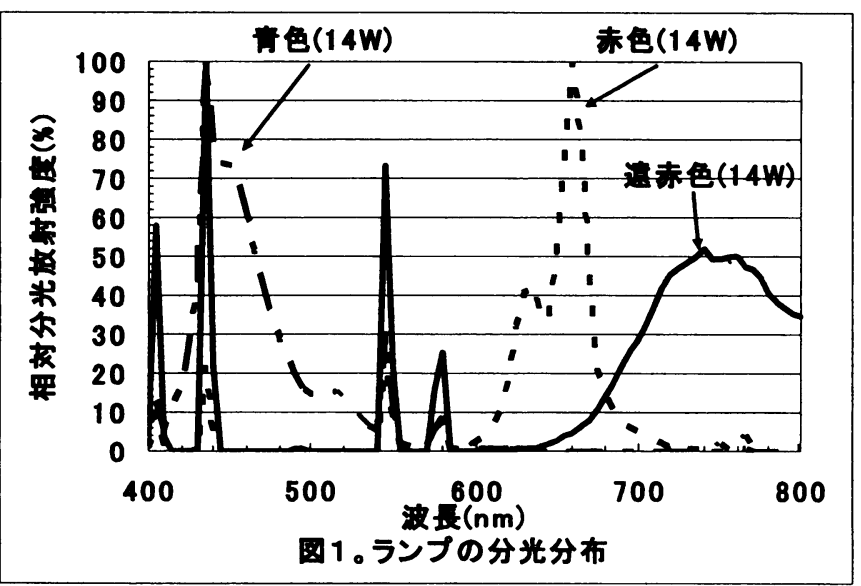

表 1 ．各試験区の水平面照度と光量子束密度

\begin{tabular}{|l|c|c|c|c|c|}
\hline \multirow{2}{*}{ 試験区 } & 水平面照度 $(\mathrm{lx})$ & \multicolumn{4}{|c|}{ 光量子束密度 $\left(\mu \mathrm{mol} \cdot \mathrm{m}^{-2} \cdot \mathrm{s}^{-1}\right)$} \\
\cline { 3 - 6 } & & $400-500 \mathrm{~nm}$ & $500-600 \mathrm{~nm}$ & $600-700 \mathrm{~nm}$ & $700-800 \mathrm{~nm}$ \\
\hline 青色 $(14 \mathrm{~W})$ & 16 & 0.50 & 0.13 & 0.06 & 0.00 \\
\hline 赤色 $(14 \mathrm{~W})$ & 26 & 0.01 & 0.05 & 1.17 & 0.03 \\
\hline 遠赤色(14W) & 10 & 0.07 & 0.07 & 0.05 & 0.35 \\
\hline
\end{tabular}

\section{3. 結果}

表 2 に各試験区の開花到達日数、開花率、草丈、葉数および節間長をそれぞれ示す。 表 2 ．各試験区の生育調查結果

\begin{tabular}{|l|c|c|c|c|c|}
\hline \multicolumn{1}{|c|}{ 試験区 } & $\begin{array}{c}\text { 開花到達日数 } \\
(\text { 日) }\end{array}$ & 開花率(\%) & 草丈(cm) & 葉数（枚） & 長(cm) \\
\hline 照明無 & 開花せず & 0 & 14.4 & 73.2 & 0.4 \\
\hline 青色(14W) & 開花せず & 0 & 15.8 & 85.6 & 0.4 \\
\hline 赤色(14W) & 108 & 31 & 62.3 & 82.4 & 1.5 \\
\hline 遠赤色(14W) & 99 & 100 & 89.6 & 79.2 & 2.3 \\
\hline
\end{tabular}

4. 結論

長日植物 ‘シュツコンカスミソウ’ は、照明無しの 8 時間日長および青色（400～500nm）照射の 場合は開花せず、赤色照射 $(600 \sim 700 \mathrm{~nm})$ では、開花、草丈伸長、花芽形成を抑制し、遠赤色照 射(700〜800nm)では、開花、草丈伸長、花芽形成を促進することが明らかになった。

Effects of the fluorescent lamp on the growth of long-day plants Gypsophila paniculata. Takayoshi.Moriyama,Keiko.Katsuta, and Koki.Kanahama 